\title{
The effects of slaughter weight and sex on some slaughter traits of Akkaraman and Morkaraman and Turkish Merino lambs*
}

\author{
Bülent TEKE ${ }^{1}$, Necmettin ÜNAL ${ }^{2}$ \\ ${ }^{1}$ Abattoir of Ankara Commodity Exchange, Yenikent - Ankara, Turkey; ${ }^{2}$ Department of Animal Breeding and Husbandry, Faculty \\ of Veterinary Medicine, University of Ankara, Dışkapı - Ankara, Turkey.
}

Summary: Some slaughter characteristics of Akkaraman, Morkaraman and Turkish Merino lambs were evaluated. The data were collected from 219 Akkaraman (181 male and 38 female) and 54 Morkaraman (32 male and 22 female) and 73 Turkish Merino (47 male and 26 female) lambs. The data were analysed by using least squares models. The models were included fixed effects of breed, empty body weight (EBW), sex and two-way interactions. Empty body weight groups with five kg ranges for each breed were constituted. Akkaraman, Morkaraman and Turkish Merino lambs showed slightly increasing dressing values with increasing EBW. The effect of empty body weight on dressing percentages was significant in Akkaraman and Morkaraman lambs $(\mathrm{p}<0.05, \mathrm{p}<0.01)$. However, the effect of sex on this trait was not pronounced in all three breeds. As EBW was increased, the percentages of the head, feet and empty digestive tract were decreased; however, the percentages of the tail and the length of small and large intestines showed a reverse trend in all investigated breeds. The effects of EBW were generally important $(p<0.05, p<0.01, p<0.001)$ for the traits mentioned above. On the other hand, the effects of sex were not usually significant $(\mathrm{p}>0.05)$ for the same traits in all breeds.

Key words: Lamb, local breeds, slaughter traits, slaughter weight, sex

\section{Akkaraman, Morkaraman ve Türk Merinosu kuzularda kesim ağırlığı ve cinsiyetin bazı kesim özelliklerine etkisi}

Özet: Akkaraman, Morkaraman ve Türk Merinosu kuzularda bazı kesim özelliklerine kesim ağırlığı ve cinsiyetin etkisi incelenmiştir. Araştırmanın hayvan materyalini 219 Akkaraman (181 erkek ve 38 dişi), 54 Morkaraman (32 erkek ve 22 dişi) ve 73 Türk Merinosu (47 erkek ve 26 dişi) kuzu oluşturmuştur. Her ırk için 5 kg sınıf aralığına sahip gruplar oluşturulmuştur. Veriler en küçük kareler yöntemi ile analiz edilmiştir. Karkas randımanı, Akkaraman, Morkaraman ve Türk Merinosu kuzularda boş canlı ağırlıkla birlikte az bir seviyede artış göstermiştir. Boş canlı ağırlığın karkas randımanına etkisi Akkaraman ve Morkaraman kuzularda önemli $(\mathrm{p}<0.01, \mathrm{p}<0.05)$, cinsiyetin etkisi ise her üç irkta da önemsiz olmuştur. Her üç irkta da boş canlı ağırlıkta artışla birlikte baş, ayak ve sindirim sisteminin (boş) oranları azalmış, kuyruk oranı ile kalın ve ince barsak uzunlukları artmıştır. Bu özelliklere boş canlı ağırlığın etkisi önemli $(\mathrm{p}<0.05, \mathrm{p}<0.01, \mathrm{p}<0.001)$, cinsiyetin etkisi ise önemsiz olmuştur.

Anahtar sözcükler: Cinsiyet, kesim ağırlı̆̆ı, kesim özellikleri, kuzu, yerli ırklar.

\section{Introduction}

The sheep population in Turkey was approximately 25.4 million in 2007 and sheep meat was constituted about $40.6 \%$ of the total red meat production with 272 thousand tons of meat, according to estimation by FAO (4). Thus sheep bears economical importance and they contribute the farmers, who live in the rural areas of the country, make a living.

Akkaraman and Morkaraman sheep are made the highest number of breeds, accounting for nearly $65 \%$ of the total sheep population in Turkey. They are fat tailed and multipurpose breeds, but low in production of milk, meat and wool. The Turkish Merino is a crossbred breed, derived from crossbreeding of German Mutton Merino with Akkaraman and Kivırcık breeds. Although the crossbreeding using the Merino began in 1928, Merino crossbreeds represented only $3 \%$ of the total number of sheep $(2,5)$.

Many studies investigating the fattening performance and slaughter and carcass traits of Akkaraman, Morkaraman and Turkish Merino breeds have been conducted so far. These studies were well reviewed by Yalçın (1986) (18) and Gürsoy (2005) (5). The previous studies on these breeds were mainly conducted on ram lambs and the data were relatively obtained from a few lambs slaughtered at main slaughter weights. So, the detailed information for the effects of sex and various slaughter weights on some slaughter characteristics of lambs of these breeds is relatively scarce. In present study, the data were obtained from both sexes and much

\footnotetext{
* This study was prepared from the senior author's $\mathrm{PhD}$ thesis.
} 
more lambs. The aim of the study was to evaluate the effects of sex and slaughter weight differences on some slaughter traits of Akkaraman, Morkaraman and Turkish Merino lambs.

\section{Materials and Methods}

The study was conducted at the Abattoir of Ankara Commodity Exchange in Turkey. The data were collected on 219 Akkaraman (181 male and 38 female) and 54 Morkaraman (32 male and 22 female) and 73 Turkish Merino (47 male and 26 female) (Central Anatolian Merino) lambs from January to June in 2004. The lambs of the study were randomly selected from the lambs slaughtered in the Abattoir. They were 4-12 months old and weighed 20-60 kg which represents the commercial age-weight slaughter range. The data were collected three times in each week during the six months period. The data were categorised in terms of empty body weight groups with five $\mathrm{kg}$ ranges for each breed. The number of lambs investigated from each breed in the study was not equal, because the number of slaughtered animals in Akkaraman breed was higher than those of Morkaraman and Turkish Merino.

Feed was withheld overnight before the slaughter, with free access to water. Before the slaughter, the breed and the sex and the slaughter weights (SW) were recorded. Then, the animals were slaughtered according to standard commercial procedures. The weight of carcass with tail (CWT), feet (cut at tarsal - metatarsal and carpal - metacarpal articulations), skin, full and empty gastrointestinal tract and head (cut at the occipital - atlantoidal articulation) were determined. Heart and lungs (including trachea) and liver and spleen were weighed as one piece (HLLS). After $4 \mathrm{~h}$ at $4{ }^{\circ} \mathrm{C}$, the tail was cut off at its base and the remaining part of the carcass was weighed (CW). A $50 \mathrm{~g}$ sensitive electronic weighing scale was used in order to scale the weights. The empty body weight (EBW) was calculated by deducting the weight of the gastrointestinal contents (full minus empty gastrointestinal tract) from the slaughter weight. The dressing percentages were calculated as carcass weight with tail and without tail divided by slaughter weight and empty body weight. The carcass length was taken from the cranial edge of the articulatio humeri to the caudal edge of tuber coxae while circumference and depth of carcass were taken from caudal edge of the scapulas. The length of small and large intestines were taken by a measuring tape on a smooth surface upon the subtraction of the intestinal contents. The percentages of head, feet, skin, tail and HLLS were calculated based on EBW while the percentage of empty digestive tract was estimated based on SW.

Data were analysed using Least Squares Model Procedures of SPSS package program (3). The models for the traits investigated were included fixed effects empty body weight groups, sex and two-way interactions between the fixed effects. When the data of three breeds were analysed, breed was included the model and common empty body weight groups for three breeds were taken into consideration. The statistical significances between the subgroups were determined with LSD test (17).

\section{Results}

The least squares means of some slaughter traits of Akkaraman lambs are shown in Table 1. The dressing percentages based on carcass weight with tail $\left(\mathrm{DP}_{1}\right)$ to slaughter weight (SW) ranged from $49.8-53.5 \%$, but the dressing percentages based on carcass weight without tail $\left(\mathrm{DP}_{2}\right)$ to SW varied among $42.8-44.3 \%$. On the other hand, the dressing percentages based on carcass weight with tail $\left(\mathrm{DP}_{3}\right)$ and without tail $\left(\mathrm{DP}_{4}\right)$ to empty body weight varied among $56.0-59.3 \%$ and $46.4-51.1$ $\%$, respectively. The differences among the EBW groups for $\mathrm{DP}_{1}, \mathrm{DP}_{3}$ and $\mathrm{DP}_{4}$ were significant $(\mathrm{p}<0.01, \mathrm{p}<0.05)$, but there were no significant differences between sexes in all dressing percentages although the females had higher values. There were significant differences among EBW groups in terms of percentages for head, feet, tail, HLLS and empty digestive tract $(p<0.001)$, but not significant for skin. Tail percentage of males was higher than females, and difference between them is statistically important $(p<0.001)$. It has been observed that length of small and large intestine ranged from $24.6-28.4 \mathrm{~m}$ $(\mathrm{p}<0.001)$ and $6.3-7.0 \mathrm{~m}(\mathrm{p}<0.05)$ among EBW groups, respectively. The effects of sex on the traits mentioned above were not significant. The two-way interaction between EBW and sex was insignificant.

The values of some slaughter characteristics of Morkaraman lambs were mentioned in Table 2. The values for $\mathrm{DP}_{1}, \mathrm{DP}_{2}, \mathrm{DP}_{3}$ and $\mathrm{DP}_{4}$ varied in a range of $47.5-50.8 \%(\mathrm{p}<0.01), 39.1-42.0 \%(\mathrm{p}<0.01), 54.9-$ $58.4 \%(\mathrm{p}<0.01)$ and $45.2-47.8 \%(\mathrm{p}<0.01)$, respectively.

Although there were no significant differences between sexes in terms of dressing percentages, the females had higher values. The percentages of head and skin among EBW groups were not significant, while the percentage of the feet, tail and HLLS among EBW groups were significant $(p<0.001, p<0.05)$. The effects of sex on those of the traits were not significant except for tail $(\mathrm{p}<0.05)$. Significant effects of EBW on differences of the length of small and large intestines $(p<0.001$, $\mathrm{p}<0.01$ ) were observed; however, there was no significant effect for sex. The two-way interaction between EBW and sex was not significant.

Table 3 contains the least squares means for some slaughter traits of Turkish merino lambs. Due to fact that Merino breed is a thin tailed breed, only $\mathrm{DP}_{1}$ and $\mathrm{DP}_{3}$ percentages are shown in Table 3 . The means of $\mathrm{DP}_{1}$ and $\mathrm{DP}_{3}$ were not affected significantly by the EBW and the sex. 


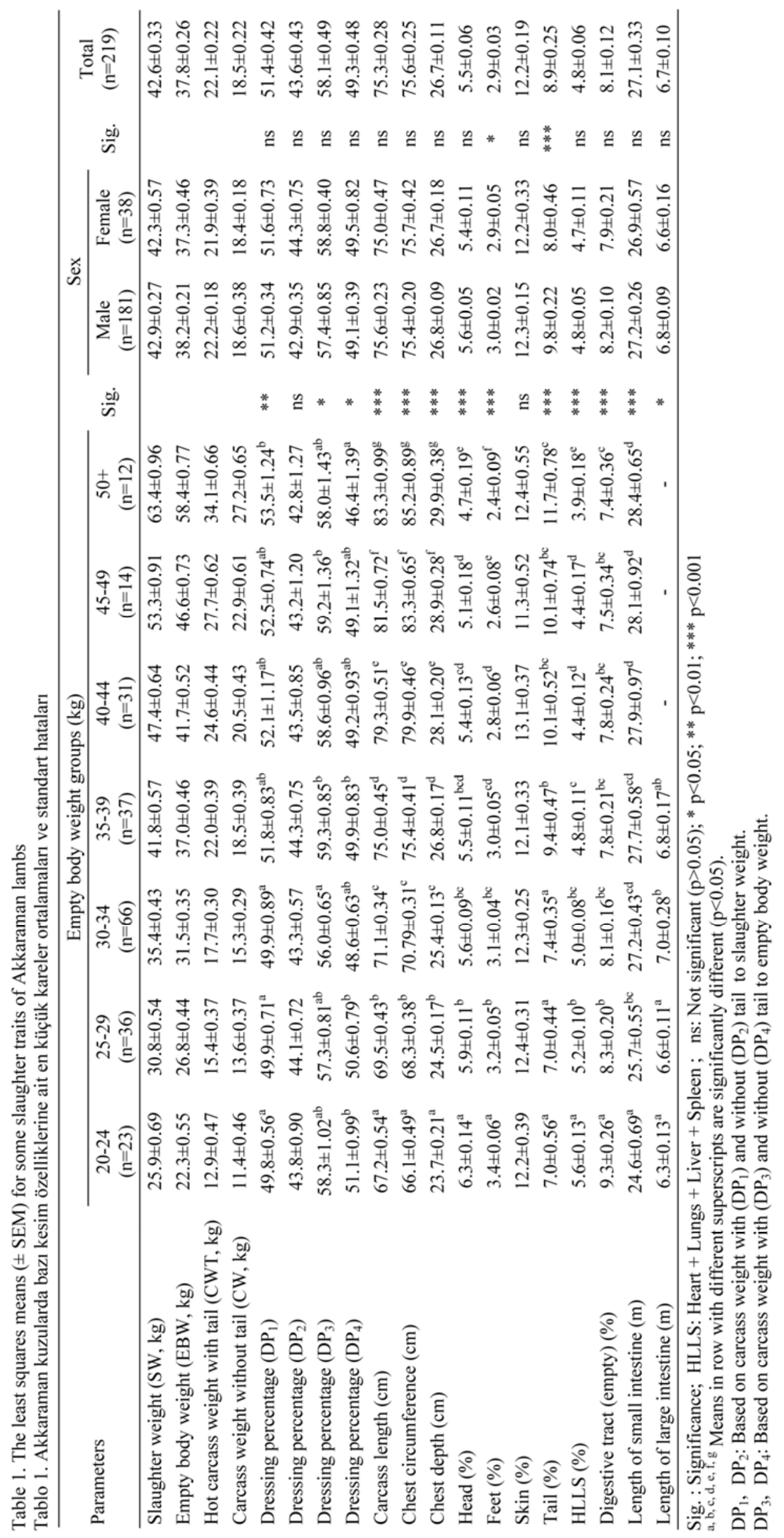


Table 2. The least squares means $( \pm$ SEM) for some slaughter traits of Morkaraman lambs

Tablo 2. Morkaraman kuzularda bazı kesim özelliklerine ait en küçük kareler ortalamaları ve standart hataları

\begin{tabular}{|c|c|c|c|c|c|c|c|c|}
\hline \multirow[b]{2}{*}{ Parameters } & \multicolumn{3}{|c|}{ Empty body weight groups (kg) } & \multirow[b]{2}{*}{ Sig. } & \multicolumn{2}{|c|}{ Sex } & \multirow[b]{2}{*}{ Sig. } & \multirow[b]{2}{*}{$\begin{array}{l}\text { Total } \\
(\mathrm{n}=54)\end{array}$} \\
\hline & $\begin{array}{c}30-34 \\
(n=24)\end{array}$ & $\begin{array}{c}35-39 \\
(n=16)\end{array}$ & $\begin{array}{c}40+ \\
(n=14)\end{array}$ & & $\begin{array}{l}\text { Male } \\
(\mathrm{n}=32)\end{array}$ & $\begin{array}{l}\text { Female } \\
(\mathrm{n}=22)\end{array}$ & & \\
\hline Slaughter weight (SW, kg) & $37.2 \pm 0.85$ & $43.0 \pm 1.04$ & $53.7 \pm 1.23$ & & $45.4 \pm 0.74$ & $43.9 \pm 0.99$ & & $44.6 \pm 0.60$ \\
\hline Empty body weight (EBW, kg) & $32.2 \pm 0.70$ & $36.1 \pm 0.85$ & $47.3 \pm 1.01$ & & $39.4 \pm 0.61$ & $37.8 \pm 0.81$ & & $38.5 \pm 0.49$ \\
\hline Hot carcass weight with tail (CWT, kg) & $17.7 \pm 0.51$ & $21.1 \pm 0.62$ & $27.3 \pm 0.74$ & & $22.2 \pm 0.44$ & $21.8 \pm 0.59$ & & $22.0 \pm 0.36$ \\
\hline Carcass weight without tail $(\mathrm{CW}, \mathrm{kg})$ & $14.5 \pm 0.44$ & $17.3 \pm 0.53$ & $22.6 \pm 0.63$ & & $18.2 \pm 0.38$ & $18.1 \pm 0.51$ & & $18.1 \pm 0.31$ \\
\hline Dressing percentage $\left(\mathrm{DP}_{1}\right)$ & $47.5 \pm 0.51^{\mathrm{a}}$ & $49.1 \pm 0.63^{\mathrm{ab}}$ & $50.8 \pm 0.74^{\mathrm{b}}$ & $* *$ & $48.9 \pm 0.60$ & $49.3 \pm 0.44$ & $\mathrm{~ns}$ & $49.1 \pm 0.36$ \\
\hline Dressing percentage $\left(\mathrm{DP}_{2}\right)$ & $39.1 \pm 0.48^{\mathrm{a}}$ & $40.2 \pm 0.59^{\mathrm{a}}$ & $42.0 \pm 0.70^{\mathrm{b}}$ & $* *$ & $40.3 \pm 0.56$ & $40.6 \pm 0.42$ & $\mathrm{~ns}$ & $40.4 \pm 0.34$ \\
\hline Dressing percentage $\left(\mathrm{DP}_{3}\right)$ & $54.9 \pm 0.71^{\mathrm{a}}$ & $57.8 \pm 1.02^{\mathrm{ab}}$ & $58.4 \pm 0.86^{\mathrm{b}}$ & $* *$ & $56.5 \pm 0.61$ & $57.6 \pm 0.82$ & $\mathrm{~ns}$ & $57.1 \pm 0.50$ \\
\hline Dressing percentage $\left(\mathrm{DP}_{4}\right)$ & $45.2 \pm 0.60^{\mathrm{a}}$ & $47.8 \pm 0.74^{\mathrm{b}}$ & $47.8 \pm 0.87^{\mathrm{b}}$ & $* *$ & $46.3 \pm 0.52$ & $47.5 \pm 0.70$ & ns & $46.9 \pm 0.43$ \\
\hline Carcass length (cm) & $69.5 \pm 0.62^{\mathrm{a}}$ & $73.1 \pm 0.75^{\mathrm{b}}$ & $77.4 \pm 0.89^{\mathrm{c}}$ & $* * *$ & $73.4 \pm 0.54$ & $73.3 \pm 0.72$ & $\mathrm{~ns}$ & $73.3 \pm 0.44$ \\
\hline Chest circumference $(\mathrm{cm})$ & $72.2 \pm 0.70^{\mathrm{a}}$ & $74.3 \pm 0.85^{\mathrm{a}}$ & $78.0 \pm 1.00^{\mathrm{b}}$ & $* * *$ & $75.3 \pm 0.61$ & $74.4 \pm 0.81$ & ns & $74.9 \pm 0.49$ \\
\hline Chest depth (cm) & $24.7 \pm 0.31^{\mathrm{a}}$ & $25.1 \pm 0.38^{\mathrm{a}}$ & $28.3 \pm 0.46^{\mathrm{b}}$ & $* * *$ & $26.3 \pm 0.27$ & $25.9 \pm 0.37$ & ns & $26.1 \pm 0.22$ \\
\hline Head $(\%)$ & $6.4 \pm 0.27$ & $6.2 \pm 0.32$ & $5.9 \pm 0.22$ & ns & $6.0 \pm 0.19$ & $6.3 \pm 0.26$ & ns & $6.1 \pm 0.16$ \\
\hline Feet $(\%)$ & $3.0 \pm 0.05^{\mathrm{a}}$ & $3.0 \pm 0.07^{\mathrm{a}}$ & $2.7 \pm 0.08^{\mathrm{b}}$ & $* * *$ & $2.9 \pm 0.05$ & $2.9 \pm 0.06$ & ns & $2.9 \pm 0.04$ \\
\hline Skin $(\%)$ & $12.5 \pm 0.35$ & $13.1 \pm 0.43$ & $12.7 \pm 0.51$ & ns & $12.7 \pm 0.31$ & $12.9 \pm 0.41$ & ns & $12.8 \pm 0.25$ \\
\hline Tail (\%) & $9.5 \pm 0.40^{\mathrm{a}}$ & $10.0 \pm 0.58^{\mathrm{ab}}$ & $10.9 \pm 0.49^{\mathrm{c}}$ & $*$ & $10.6 \pm 0.47$ & $9.6 \pm 0.35$ & $*$ & $10.1 \pm 0.28$ \\
\hline HLLS (\%) & $5.3 \pm 0.23^{\mathrm{b}}$ & $4.9 \pm 0.16^{\mathrm{ab}}$ & $4.4 \pm 0.19^{\mathrm{a}}$ & $*$ & $5.0 \pm 0.14$ & $4.7 \pm 0.19$ & $\mathrm{~ns}$ & $4.9 \pm 0.11$ \\
\hline Digestive tract (empty) (\%) & $8.8 \pm 0.16^{\mathrm{a}}$ & $8.0 \pm 0.19^{\mathrm{b}}$ & $7.6 \pm 0.23^{\mathrm{b}}$ & $* * *$ & $8.2 \pm 0.14$ & $8.1 \pm 0.19$ & $\mathrm{~ns}$ & $8.1 \pm 0.11$ \\
\hline Length of small intestine (m) & $27.1 \pm 0.48^{\mathrm{a}}$ & $28.4 \pm 0.59^{\mathrm{a}}$ & $32.9 \pm 0.70^{\mathrm{b}}$ & $* * *$ & $29.6 \pm 0.42$ & $29.4 \pm 0.42$ & $\mathrm{~ns}$ & $29.5 \pm 0.34$ \\
\hline Length of large intestine (m) & $6.3 \pm 0.16$ & $7.2 \pm 0.32$ & - & $* *$ & $6.9 \pm 0.26$ & $6.6 \pm 0.21$ & ns & $6.7 \pm 0.18$ \\
\hline
\end{tabular}

Sig. : Significance; HLLS: Heart + Lungs + Liver + Spleen ; ns: Not significant $(\mathrm{p}>0.05) ;{ }^{*} \mathrm{p}<0.05 ;{ }^{* *} \mathrm{p}<0.01 ;{ }^{* *} \mathrm{p}<0.001$

$\mathrm{a}, \mathrm{b}, \mathrm{c}$ Means in row with different superscripts are significantly different $(\mathrm{p}<0.05)$.

Table 3. The least squares means ( \pm SEM) for some slaughter traits of Turkish Merino lambs

Tablo 3. Türk Merinosu kuzularda bazı kesim özelliklerine ait en küçük kareler ortalamaları ve standart hataları

\begin{tabular}{|c|c|c|c|c|c|c|c|c|c|c|}
\hline \multirow[b]{2}{*}{ Parameters } & \multicolumn{5}{|c|}{ Empty body weight groups (kg) } & \multirow[b]{2}{*}{ Sig. } & \multicolumn{2}{|c|}{ Sex } & \multirow[b]{2}{*}{ Sig. } & \multirow{2}{*}{$\begin{array}{l}\text { Total } \\
(\mathrm{n}=73)\end{array}$} \\
\hline & $\begin{array}{c}20-24 \\
(\mathrm{n}=12)\end{array}$ & $\begin{array}{l}25-29 \\
(\mathrm{n}=19)\end{array}$ & $\begin{array}{c}30-34 \\
(\mathrm{n}=20)\end{array}$ & $\begin{array}{c}35-39 \\
(\mathrm{n}=11)\end{array}$ & $\begin{array}{c}40+ \\
(\mathrm{n}=11)\end{array}$ & & $\begin{array}{c}\text { Male } \\
(\mathrm{n}=47)\end{array}$ & & & \\
\hline Slaugnter weignt & $25.2 \pm 1.01$ & $31.3 \pm 0.80$ & $35.8 \pm 0.79$ & $1.3 \pm 1.09$ & $51.7 \pm 1.15$ & & $37.5 \pm 0.52$ & 36.6 & & \\
\hline ) & $22.4 \pm 0.89$ & $27.5 \pm 0.72$ & $31.7=$ & $37.1 \pm 0.97$ & $45.9 \pm 1.02$ & & $33.6 \pm 0.46$ & 32. & & 41 \\
\hline & $12.6 \pm 0.59$ & $16.0 \pm 0$ & $18.5 \pm 0.47$ & $21.9 \pm 0.64$ & $27.4 \pm$ & & $19.6 \pm 0.45$ & $18.9 \pm$ & & $19.3 \pm 0.27$ \\
\hline (DP & $49.9 \pm$ & $51.3 \pm 0.85$ & $51.6=$ & 1.16 & 22 & ns & $51.0 \pm 0.55$ & 52.8 & ns & 51.9 \\
\hline percentage & $56.2 \pm 1.0$ & $582+0$ & $582+$ & $592+114$ & $602+4$ & ns & $57.8 \pm 0.54$ & 59.0 & ns & $58.4 \pm 0.48$ \\
\hline ss length $(\mathrm{cm})$ & $64.1 \pm 0.69^{\mathrm{a}}$ & $68.3 \pm 0.55^{\mathrm{b}}$ & $70.7 \pm 0.54^{\mathrm{c}}$ & $72.5 \pm 0.78^{\mathrm{d}}$ & $78.8 \pm 0.79^{\mathrm{e}}$ & $* * *$ & $71.2 \pm 0.36$ & 70.6 & ns & $70.9 \pm 0.32$ \\
\hline Ches & $66.0 \pm$ & $69.7 \pm 0$ & $72.9 \pm 0.69^{c}$ & $76.3 \pm 0.99^{\mathrm{d}}$ & $83.0 \pm 1.00^{\mathrm{e}}$ & $* * *$ & $73.7 \pm 0.46$ & 73. & ns & \pm 0.40 \\
\hline & $22.4 \pm 0.35^{\mathrm{a}}$ & $23.8 \pm 0.28^{\mathrm{b}}$ & $24.6 \pm 0.27^{\mathrm{c}}$ & $24.8 \pm 0.39^{c}$ & $28.0 \pm 0.40^{\mathrm{d}}$ & $* * *$ & $25.0 \pm 0.18$ & 24. & ns & 0.16 \\
\hline & $6.4 \pm$ & & $5.7 \pm$ & $5.2 \pm$ & & $* * *$ & $6.1 \pm 0.10$ & .14 & $* * *$ & $5.7 \pm 0.09$ \\
\hline & $3.2 \pm 0.08^{\mathrm{a}}$ & $2.9 \pm 0.07^{b}$ & $2.8 \pm 0.07^{\mathrm{b}}$ & $2.5 \pm 0.09^{c}$ & $2.6 \pm 0.09^{\mathrm{bc}}$ & $* * *$ & $3.0 \pm 0.04$ & $2.7 \pm 0.06$ & $* * *$ & $2.8 \pm 0.04$ \\
\hline $\mathrm{S}$ & $10.6 \pm$ & $10.1 \pm$ & $10.6=$ & $10.3 \pm 0.49$ & $10.5=$ & ns & $10.6 \pm 0.23$ & 10.2 & ns & $10.4 \pm 0.20$ \\
\hline HLLS (\%) & $5.8 \pm 0.18$ & $5.5 \pm 0.15$ & $5.3 \pm 0.15$ & $5.1 \pm 0.20$ & $4.7 \pm 0.21$ & $* * *$ & $5.4 \pm 0.09$ & $5.2 \pm 0.14$ & $\mathrm{~ns}$ & $5.3 \pm 0.08$ \\
\hline $\begin{array}{l}\text { Digestive tr } \\
(\%)\end{array}$ & $9.7 \pm$ & $8.5 \pm 0.21^{\mathrm{b}}$ & $21^{\mathrm{bc}}$ & $7.8 \pm 0.31^{\mathrm{bc}}$ & $29^{c}$ & $* * *$ & $8.3 \pm 0.14$ & .20 & ns & $8.3 \pm 0.12$ \\
\hline nall & $25.4 \pm 0.80^{\mathrm{a}}$ & $25.8 \pm 0.64^{\mathrm{ab}}$ & $27.1 \pm 0.63^{b}$ & $25.0 \pm 0.87^{\mathrm{ab}}$ & $29.3 \pm 0.92^{\mathrm{c}}$ & $* *$ & $26.6 \pm 0.42$ & $26.4 \pm 0.61$ & ns & $26.5 \pm 0.36$ \\
\hline $\begin{array}{l}\text { Length of large intestine } \\
(\mathrm{m})\end{array}$ & $5.5 \pm 0.22^{\mathrm{a}}$ & $0 \pm 0.22^{\mathrm{b}}$ & $6.4 \pm 0.28^{\mathrm{c}}$ & - & - & $*$ & $6.0 \pm 0.18$ & $5.9 \pm 0.21$ & ns & $6.0 \pm 0.14$ \\
\hline
\end{tabular}

Sig. : Significance; HLLS: Heart + Lungs + Liver + Spleen; ns: Not significant $(\mathrm{p}>0.05) ;{ }^{*} \mathrm{p}<0.05 ;{ }^{* *} \mathrm{p}<0.01 ; * * * \mathrm{p}<0.001$

$\mathrm{a}, \mathrm{b}, \mathrm{c}, \mathrm{d}, \mathrm{e}$ Means in row with different superscripts are significantly different $(\mathrm{p}<0.05)$ 


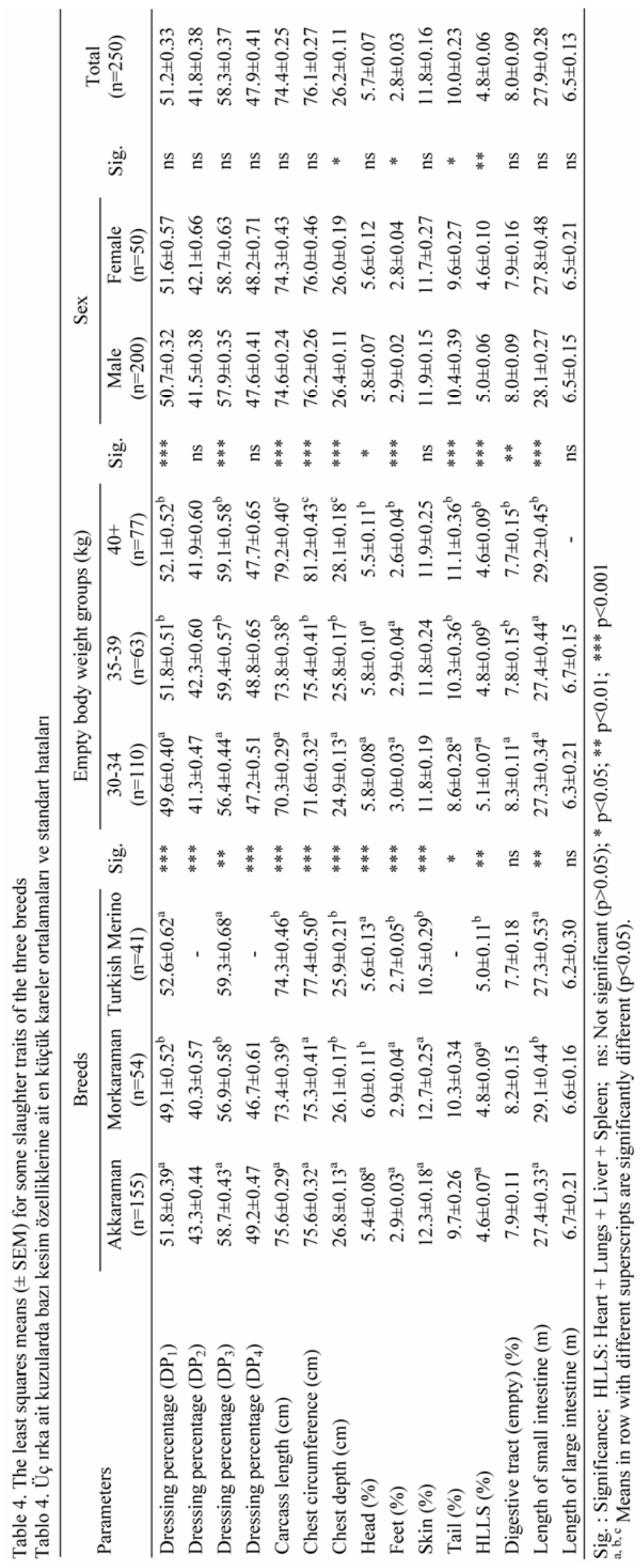


EBW had significant effects on the percentages of head, feet and HLLS $(\mathrm{P}<0.001)$, while there was no significant effect on skin percentage. The differences in percentages of head and feet between sexes were significant $(p<0.001)$. The effect of EBW was significant $(p<0.01$, $\mathrm{p}<0.05)$ for the lengths of small and large intestines. The two-way interaction between EBW and sex was insignificant.

The least squares means of some slaughter traits of the three breeds were presented in Table 4 . The numbers of animals in Table 4 were appeared different from the other tables because the common empty body weight groups were taken into consideration. The effects of breed on the traits investigated were significant $(p<0.05$, $\mathrm{p}<0.01, \mathrm{p}<0.001)$ except for empty digestive tract and length of large intestine. All two-way interactions among fixed effects were not significant.

\section{Discussion and Conclusion}

The variation in weight of digestive tract contents in lambs before slaughter is a problem with evaluating some of slaughter traits. Withholding of feed before slaughter is a common procedure used in attempting to overcome this difficulty. This procedure, however, might be not entirely satisfactory. So, it could be said that using data of empty body weight to analyse of effects of some factors on slaughter traits increases precision. In the present study, the data were categorised in terms of empty body weight.

Dressing percentages in Akkaraman lambs based on carcass weight with tail to slaughter weight $\left(\mathrm{DP}_{1}\right)$ showed a regular pattern as empty body weight increased (Table 1). These results were consistent with those of literature that reported an increase in Akkaraman (1, 6, $15)$ and other breeds $(7,9,11,15)$ when slaughter weight increased. On the other hand, dressing percentages based on carcass weight with tail $\left(\mathrm{DP}_{3}\right)$ and without tail $\left(\mathrm{DP}_{4}\right)$ to empty body weight did not display a regular pattern when empty body weight increased. The dressing percentages of Akkaraman breed in literatures were generally based on carcass weight with tail to slaughter weight $\left(\mathrm{DP}_{1}\right)(6,14,15,16)$. The means of $\mathrm{DP}_{1}$ were similar with those reported previous studies $(6,14,15$, 16) conducted under intensive conditions on Akkaraman; $47-53 \%$. The tail is cut at the basis when marketing of carcasses in Turkey and that of price is lower than meat. So dressing percentage based on carcass weight without tail $\left(\mathrm{DP}_{2}, \mathrm{DP}_{4}\right)$ has more importance than $\mathrm{DP}_{1}$ and $\mathrm{DP}_{3}$ in terms of commercial market. Although the differences between sexes were not generally significant, the female lambs of Akkaraman displayed higher dressing percentages than males. Kremer et al. (2004) (7) and Perez et al. (2007) (11) reported that female lambs had higher dressing percentage and this might be associated to a higher fat deposition in the carcass, and pointed out that there was an increase in dressing percentage with an increase in body weight.

A significant decrease in the percentage of head, feet and Heart+Lungs+Liver+Spleen (HLLS); though a significant increase in the percentage of tail, with increase in EBW was observed in Akkaraman lambs, and this is consistent with results obtained before $(1,6,8,11$, 15). The differences in the percentage of head, feet and HLLS between sexes weren't significant, but significant for tail. It has been reported $(10,11)$ that the studies on the difference between sexes in some slaughter and carcass traits of sheep breeds are little, and in general there are some degrees of uncertainty on how sexes differ in this respect. However, there is a common view that ram lambs have higher proportions of fat in the carcass and lower proportions of non-carcass fat depots than ewe lambs. Negussie et al. (2003) (10) working with fattailed Menz and Horro sheep breeds found that male lambs had higher tail fat than females slaughtered at various body weight, and Perez et al. (2007) (11) working with four different genotypes (Suffolk, Merino Precoz, Suffolk crossbreds with Merino Precoz and Corriedale) found that male and female lambs had similar values for feet and heart and liver percentages. The results of this study are in line with the results reported above.

The percentages of skin in Akkaraman lambs were not affected significantly by empty body weight, being consistent with the results of the other studies $(8,11,15$, 16). Ünal et al. (2006) (16) reported that lambs from Akkaraman and its crossbred with Kivircik and Chios breeds showed a similar percentage of skin, ranged from 10.9 to $13.1 \%$. An increase in EBW caused a decrease in the percentage of the empty digestive tract, and there was no significant effect of sex on that trait while the males had higher values than females. The male lambs of Pelibuey Hair Sheep and crossbred (Rambouillet $\mathrm{x}$ Pelibuey) had higher empty digestive tract than those of female lambs (7.8 vs. $6.9 \%$ and 7.9 vs. $7.0 \%$, respectively) slaughtered at $30 \mathrm{~kg}$ body weight (12). But, Perez et al. (2007) (11) observed that male lambs from four different genotypes had lower percentages for empty digestive tract than females (12.0 vs. $12.6 \%$ ). The data for length of large intestine for the last three EBW groups were missed because the application of procedure applied by slaughterhouse didn't give possibility to collect those of data.

Due to the fact that it is the most common in Eastern Anatolia, the number of Morkaraman lambs in this study was lower than Akkaraman which is the dominant breed in Central Anatolia. So, the results for Morkaraman could be presented in three EBW groups (Table 2). The findings in this study for $\mathrm{DP}_{1}$ of 
Morkaraman lambs are similar with those reported on Morkaraman lambs derived from carcass and slaughter weights, varied in a range of 51-53\% $(6,8)$. The averages of $\mathrm{DP}_{3}$ for Morkaraman lambs were lower than those of Akkaraman lambs and the differences between Akkaraman and Morkaraman lambs were significant in the present study (Table 4). The dressing percentages recorded by the studies $(1,8)$ that were conducted using Akkaraman and Morkaraman breeds showed that Akkaraman lambs had higher performance. On the other hand, Kadak (1983) (6) reported that Morkaraman lambs had higher dressing percentages than Akkaraman lambs, although the differences were not significant. In the present study, there were statistically significant differences between Akkaraman and Morkaraman lambs in terms of $\mathrm{DP}_{1}, \mathrm{DP}_{3}$, head percentage and length of small intestine. On the other hand, a decrease in the percentage of head, feet and HLLS in Morkaraman, with increase in EBW, were similar to Akkaraman (Table 1 and 2). With an increase in EBW, a significant decrease was observed in percentage of empty digestive tract in Morkaraman lambs. Females were similar to males in terms of empty digestive tract in all EBW groups. An increase in length of small intestine was observed when EBW increased, resulting in $5.8 \mathrm{~m}$ difference between the groups of 30-34 $\mathrm{kg}$ and $40+\mathrm{kg}$ (Table 2). The results in this study indicated that the lengths of small intestines of Morkaraman were higher than Akkaraman.

The number of Merino lambs in this study was lower than those of Akkaraman and Morkaraman lambs. This is expected because number of Merino is very low in sheep population. When the findings for Turkish Merino lambs are evaluated, $\mathrm{DP}_{1}$ was increased with the increase of EBW, although the differences among the groups were not significant. $\mathrm{DP}_{1}$ obtained for Merino lambs in this study are higher than those reported for the same breed lambs slaughtered at $44 \mathrm{~kg}$ (45\%) (14), but similar to Merino Branco lambs slaughtered at 24 and 30 $\mathrm{kg}$ (52 and $52 \%)(13)$ and Merino Precoz lambs (55\%) slaughtered at $15 \mathrm{~kg}$ (11). It is clear from Table 3 that carcass measurements increased with the increase of EBW. The decrease in the percentages of head, feet and HLLS with increasing in EBW of Turkish Merino, thin tailed breed, was similar to those obtained for fat tailed Akkaraman and Morkaraman sheep. A significant decrease was observed in percentage of empty digestive tract with an increase in EBW, consistent with the results of Akkaraman and Morkaraman lambs in the present study (Table 1, 2 and 3). A significant increase in the lengths of small and large intestines was detected when EBW increased. This result is also consistent with the results of Akkaraman and Morkaraman in the present study. The effect of breed on the length of small intestine was significant. This may be have an influence on the breed differences of physiological properties such as digestibility of the feeds especially roughage. On the other hand, the values of $\mathrm{DP}_{1}$ and $\mathrm{DP}_{3}$ of Turkish merino lambs were higher than Morkaraman lambs, but similar to Akkaraman lambs (Table 4). Akkaraman and Morkaraman lambs, fat tailed breeds, had higher means of feet and skin percentages than Turkish Merino lambs, thin tailed breed.

In conclusion, lambs of Akkaraman, Morkaraman and Turkish Merino showed slightly increasing dressing values with increasing empty body weights, and the effect of empty body weight on dressing percentage were generally significant except Turkish Merino lambs. While the effect of sex on this trait was not stated, the females had generally higher values than males. Despite the percentages for head, feet, Heart+Lungs+Liver+ Spleen and empty digestive tract were lessened as empty body weight increased in all breeds, the percentages for the tail, lengths of small and large intestines were increased. Although the females displayed lower values, sex was not statistically effective on those of traits.

\section{Acknowledgements}

The authors thank Prof. Dr. Halil AKÇAPINAR for his valuable assistance, and also thank the staff at the Abattoir of Ankara Commodity Exchange where the lambs were slaughtered.

\section{References}

1. Akçapınar H (1981): Dağllı̧, Akkaraman ve Klvirclk kuzularınin farkl kesim ağırlkklarında et verimi ve karkas değeri üzerinde karşılaştırmalı araştırmalar. Ankara Univ Vet Fak Derg, 28, 112-129.

2. Akçapınar H (2000): Koyun Yetişstiriciliği. 109-114, İsmat Matbaacil1k, ISBN 975-96978-1-5, Ankara.

3. Anonymous (2001): Statistical Package in Social Science for Windows. Statistical Innovations Inc., Version 10.0 (Serial Number 9024147), Chicago, USA.

4. Anonymous (2008): Food and Agriculture Organization: Statistical Databases (http://faostat.fao.org).

5. Gürsoy O (2005): Small ruminant breeds of Turkey. 239416. In: L. Iniguez (Ed) Characterization of Small Ruminant Breeds in West Asia and North Africa, $1^{\text {st }}$ Ed, Volume 1, ICARDA, Jordan.

6. Kadak R (1983): Akkaraman, Morkaraman ve İvesi Irk Kuzuların Farklı Kesim Ağırlkklarında Besi Performansı ve Karkas Özelliklerinin Karşılaş̧tırlması. Doktora Tezi, Fırat Üniversitesi Sağlık Bilimleri Enstitüsü, Elazığ.

7. Kremer R, Barbato G, Castro L, Rista L, Roses L, Herrana V, Neirotti V (2004): Effect of sire breed, year, sex and weight on carcass characteristics of lambs. Small Rum Res, 53, 117-124.

8. Macit M (2002): Growth and carcass characteristics of male lambs of the Morkaraman breed. Small Rum Res, 43, 191-194.

9. Miguel E, Huidobro FR, Blazquez B, Velasco S, Lauzurica S, Perez C, Caneque V (2007): Live weight 
effect on the prediction of tissue composition in suckling lamb carcasses using the European Union scale. Small Rum Res, 67, 199-208.

10. Negussie E, Rottmann OJ, Pirchner F, Rege JE O (2003): Patterns of growth and partitioning of fat depots in tropical fat-tailed Menz and Horro sheep breeds. Meat Sci, 64, 491-498.

11. Perez P, Maino M, Morales MS, Köbrich C, Bardon C, Pokniak J (2007): Gender and slaughter weight effects on carcass quality traits of suckling lambs from four different genotypes. Small Rum Res, 70, 124-130.

12. Pineda J, Palma JM, Haenlein GFW, Galina MA (1998): Fattening of Pelibuey hair sheep and crossbreds (Rambouillet-Dorset $x$ Pelibuey) in the Mexican tropics. Small Rum Res, 27, 263-266.

13. Silva JS, Mendes IA, Bessa RJB (2002): The effect of genotype, feeding system, and slaughter weight on the quality of light lambs. 1. Growth, carcass composition and meat quality. Livest Prod Sci, 76, 17-25.

14. Tekin ME, Akmaz A, Kadak R, Nazlı M (1993): The fattening and carcass characteristics of Akkaraman, Awassi and Turkish Merino male lambs. Hay Araşt Derg, 3, 98-102.
15. Tufan M (1997): Farklı Kesim Ağırlıklarında Kesilen Güney Karaman, Kangal Akkaraman ve Akkaraman Kuzularında Besi Performansl, Kesim ve Karkas Özellikleri. Doktora Tezi, Selçuk Üniversitesi Sağlık Bilimleri Enstitüsü, Konya.

16. Ünal N, Akçapınar H, Aytaç M, Atasoy F (2006): Fattening performance and carcass traits in crossbred ram lambs. Medycyna Wet, 62, 401-404.

17. Wayne WD (1991): Biostatistics: A Foundation for Analysis in the Health Sciences. $5^{\text {th }}$ ed, Wiley Series, New York, USA.

18. Yalçın BC (1986): Sheep and Goats in Turkey. 31-72, FAO Animal Production and Health Paper, Rome.

Geliş tarihi: 23.06.2008 / Kabul tarihi: 25.11.2008

\section{Address for correspondence}

Assoc. Prof. Dr. Necmettin Ünal

Department of Animal Breeding and Husbandry, Faculty of Veterinary Medicine,

University of Ankara, Dışkapl - Ankara, Turkey. Tel: +903123170315 Fax: +903123164472 e-mail:unal@veterinary.ankara.edu.tr 